\title{
DEVELOPMENT OF INFORMATION AND COMMUNICATION TECHNOLOGY (ICT) SKILLS AMONG STUDENTS WITH LEARNING DISABILITIES (SLD) IN MALAYSIA AND UKRAINE
}

\author{
Rohaizat binti Ibrahim ${ }^{1}$, Noraini Abdullah², Ciptro Handrianto ${ }^{3}$, Irna Liza Muliana ${ }^{4}$, \\ Nataliia Nykonenko 5
}

${ }^{1,2,3,4}$ Sultan Idris Education University, Malaysia

${ }^{5}$ Oles Honchar Dnipro National University, Ukraine

Corresponding author: rohaizat82@yahoo.com

\begin{tabular}{|c|c|}
\hline Article Info & Abstract \\
\hline $\begin{array}{l}\text { Received: } 21 \text { June } 2021 \\
\text { Accepted: } 21 \text { July } 2021 \\
\text { Published: } 26 \text { October } 2021\end{array}$ & $\begin{array}{l}\text { This study aims to develop Information and Communication } \\
\text { Technology (ICT)'s skills for Students with Learning Disabilities } \\
\text { (SLD) in Malaysia and Ukraine. The methodology used in this study } \\
\text { is based on the Universal Learning Design implementation, which }\end{array}$ \\
\hline $\begin{array}{l}\text { Keywords: } \\
\text { Information and } \\
\text { communication technology; } \\
\text { students with learning } \\
\text { disabilities }\end{array}$ & $\begin{array}{l}\text { Integration and Assessment. The Preparation and Integration Phases } \\
\text { are the stages for designing ICT activities and practicing digital skills. } \\
\text { While the Assessment Phase is the phase to determine the usability of } \\
\text { ICT for SLD. The findings of the study show that the Preparation and } \\
\text { Integration Phases study are the most effective types of activities for } \\
\text { digital skills development. It is obtained from the opinion of the experts } \\
\text { in ICT related to learning content ranging from simple to complex with } \\
\text { a defuzzification value of 0.939. The results of the Assessment Phase } \\
\text { show that SLD can develop their ICT's skills by using videos related } \\
\text { to real situations. It also provides SLD with activities that can build a } \\
\text { communication network between them and public and private } \\
\text { institutions. All these activities were provided to stimulate and } \\
\text { motivate them to work hard to achieve the desired goals, which are to } \\
\text { meet the needs of SLD and known as "ICT skills". }\end{array}$ \\
\hline
\end{tabular}

\section{INTRODUCTION}

Students with Learning Disabilities (SLD) are children with neurological problems, identified and confirmed by a physician as related to the way the brain receives, processes, analyses and stores information. They also have impairments in one or more of the psychological processes involving comprehension, use of oral or written language. This disorder can affect their ability to hear, think, speak, read, write, spell or count (Bahagian Pendidikan Khas, 2015). In addition, the Special Education Division also categorizes SLD as Dyslexic children, Attention Deficit Hyperactivity Disorder (ADHD), slow learners, Autisme, Down Syndrome or children with mild intellectual disabilities. Based on the statement above, it is clear that SLD has one or a variety of disabilities but can still be taught and benefit from the national education system. 
The scholars in this field have given their opinion that SLD should be exposed to career education programs as the existing academic curriculums could not facilitate their potential development. Furthermore, they also experience low self-concept (Pestana, 2015), poverty problems (Brucker, Mitra, Chaitoo, \& Mauro, 2015), discrimination problems (Hargreaves \& Walker, 2014) and having the most critical problems of making their educational and career choice decisions (Trainor, Smith, \& Kim, 2012). As a result, summarized by Aina (2010), the majority of SLD became beggars, tissue sellers or street musicians after graduating from high school.

Above the mentioned, SLD is limited in obtaining modern professions and practicing them in their independent adult life as they are primarily related to gaining digital skills. Thus, according to the data collected by the previous researchers, individuals with disabilities don't have equal access to ICT and are not experienced in using such tools. The majority of American teachers participating in the survey (Klein, 2021) witnessed that the pandemic challenge was the most negative impact on students out of economically disadvantaged families (34\%) and students with special educational needs (24\%). Furthermore, most students could not get access to career education programs on building, nursing etc., as there were only $15 \%$ of internship programs available during the pandemic (Klein, 2021).

Obviously, Information and Communication Technology (ICT) skills have become an important component of career education programs (Daud, 2019). Hegarty et al. (2000) introduced the definition of ICT as a psychological tool (attitude and self-confidence) for special education students. IDEA (2004) defines ICT as an equipment or products used to enhance and maintain the capabilities of SLD. Morgan et al. (2006); Zalaquette and Osborn (2007) also stated that the definition for ICT is vague, but its function is the same, which is to facilitate SLD to obtain extensive and up-to-date information while Bouck and Hunley (2014) define ICT as an assistive technology categorized into three levels, namely low technology, medium technology and high technology according to the capabilities of SLD.

Inclusion of students with special educational needs in all aspects of contemporary life of the globalized world means organizing equal access and rights to obtain the appropriate education responding to their needs. Since ICT is an essential component of our modern lifestyle, students with disabilities should obtain digital skills to use them in the professional and everyday activities. The experience of developing digital skills and teaching online special education students indicates the efficacy of the trend (Handrianto \& Salleh, 2019). The results of the comprehensive investigation of the effectiveness of online education for special education students, conducted by Larwin and Erickson (2016), suggest that "the achievement level of the typical students with disabilities did not differ from the achievement of students in the control group". They also prove that students with special educational needs demonstrate better academic achievements being in distance education than face-to-face classrooms. The mentioned above is valid for students with severe disabilities (Eliwarti \& Maarof, 2014; McDonnell, Jameson, Riesen, Polychronis, Crockett, \& Brown, 2011). Catalano (2014) states that using principles of universal design for obtaining positive results of teaching classes with students with different types of disabilities is of great importance. The research work done by all the researchers shows that ICT is very important to give special education students a better and effective education. 
Wehman et al. (2007) have conducted a study related to the acceptance of SLD on career education programs by using ICT. They found that as many as $50 \%$ of Persons with Disabilities (PWD), including SLD did not use online career education programs. These findings were further reinforced by the study of Raghavendra et al. (2013), who found that SLD still have low potential to use online services to explore their learning information. According to Ferri and Giannoumis (2014) everything was based on the weakness of career education program software that is not inclusive for SLD. As a result, SLD have difficulty in determining the direction of their education.

Special education students need to be provided with activities that use ICT such as websites that can be functioned for 24 hours. In addition, students also need to be exposed to activities based on their existing knowledge to facilitate them to understand the concept of learning (Handrianto, Rasool, Rahman, Musta`in, \& Ilhami, 2021; Ng'ambi \& Johnson, 2006). Ementors can give an impact on the excellence of special education students by using ICT. Ementor is a combination of the words email and mentor. In this study, special education students were given a mentor who could be contacted via e-mail to obtain guidance, assistance, motivation and guidance on education, career development and emotions of special education students (Handrianto, Salleh, \& Chedi, 2020; Khalil, 2008). Special education students prefer to use mobile phones rather than computers in accessing their career information and even special education students also show high interest if the activity was accompanied by interesting graphics, colors, videos and images (Bowlsbey, 2013). That's why implementation of e-portfolios is observed as a useful tool for developing traditional and non-traditional domains in special education students even with severe disabilities (Clancy, 2017).

SLD is more in touch with their peers via electronic mail than with mentors when obtaining information. As a result, they use DO-IT more for social purposes than for education and careers. This situation indicates that SLD lack focus and proper technique is important to maintain their momentum during the information seeking process (Burgstahler \& Cronheim, 2001; Eliwarti \& Maarof, 2017). Obviously that SLD need equipment to use computers, CD players or radios (Nkansah \& Unwin, 2010). Furthermore, visually impaired students need to be provided with computer equipment, internet, digital sound recording, radio, compact disc (CD) or speech software while students with hearing impairment need a computer, internet, $\mathrm{CD}, \mathrm{LCD}$ or television.

Efficient development of ICT skills with special education students seems problematic in the case their teachers don't obtain the mentioned skills themselves (Daud, 2014). Safani, Mohd Hanafi and Mussidiq (2013) had also conducted a study on the use of computers among special education teachers. A total of 86 special education teachers in Klang were involved in this survey study. The results of their study found that there is a high need for special education teachers to use computers in their teaching and learning sessions. This is because special education students are more likely to respond positively when learning using computers compared to traditional methods. McDonnell et al (2011) compared on-campus and distance education programs for teacher of students with severe disabilities and summarized the necessity for special education teachers to upgrade digital skills as the academic achievements in both groups do not differ significantly. Having analyzed the results of the survey among 435 initial group of special educators and 135 in-service special educators conducted during the first months of COVID-19 pandemic launching. Shevtsov et al (2020) proved the need to develop a special software program for developing ICT skills with the teachers of students with 
special educational needs, due to the facts that educational systems appeared not to be prepared for online learning immediate implementation and the educators faced the lack of welldeveloped digital skills.

As soon as the pandemic rapidly increased the necessity for all stakeholders of education in gaining digital skills. This study aims to develop a form of ICT skills activities as a career education program for SLD. In addition, this study also aims to evaluate the applicability of ICT to SLD. Based on the background study that had been stated, the objectives of the study are constructed to elaborate specifically on the study conducted. Therefore, the objectives to be achieved here are: (1) To identify the types of activities that should be present in developing ICT skills for SLD according to the agreement of the Fuzzy Delphi panel; and (2) To identify the extent of applicability in developing ICT skills for SLD according to the Fuzzy Delphi panel view agreements.

\section{METHOD}

The research design in this study is to use three Phases which are consist of Preparation Phase, the Integration Phase and the Assessment Phase. In the context of our study, the Preparation Phase and the Integration Phases are combined for the development of ICT skills. In this order appropriate activity forms were obtained through the Fuzzy Delphi method. At the Assessment Phase the Fuzzy Delphi method uses only the total score of the Preparation and Integration Phases Findings; a panel of experts suggested that there should be at least 5 activities for the ICT skills development in SLD. The respondents which are the SLDs participated in this research in Assessment Phase is 55 in Malaysia while 48 respondents in Ukraine.

\section{FINDINGS}

The Preparation Phase and the Integration Phase are an important stage in developing ICT skills for SLD. Therefore, the researchers had selected 11 Fuzzy Delphi panellists covering three main fields (Special Education, ICT and Psychology/Counseling) in Malaysia and 55 experts in the mentioned areas in Ukraine. There are two analyses used in the Preparation and Integration Phases. In the Preparation Phase, Fuzzy Delphi analysis was used in the Integration Phase. Creswell (2008) has listed four main steps in analyzing qualitative data, namely (1) collecting all the information for analysis; (2) reading the interview transcript; (3) the data coding process and (4) theme formation.

Next, the researcher made a code analysis by grouping the codes in the same group and identifying the existence of the most recent codes as a result of the interview transcripts. The coding process stops if there are three to four themes resulting as suggested by Creswell (2008). According to Mohd Ridhuan et al. (2014) there are several conditions need to be followed in analyzing the Fuzzy Delphi method. The conditions include (i) determining the threshold value, (ii) calculating the expert consensus value and (iii) defuzzification. To determine the threshold value (d), the researcher used the formula below: 


$$
d(\tilde{m}, \tilde{n})=\sqrt{\frac{1}{3}\left[\left(m_{1}-n_{1}\right)^{2}+\left(m_{2}-n_{2}\right)^{2}+\left(m_{3}-n_{3}\right)^{2}\right]} .
$$

Based on the formula, if the threshold value obtained is $\mathrm{d} \leq 0.2$, then the item is accepted and if otherwise then the item is rejected or the next round done, while the calculation of expert consensus value must exceed $75 \%$. Next, the defuzzification value or fuzzy score of A was analyzed using the formula below:

$$
A=(1 / 3) *(m 1+m 2+m 3)
$$

\section{A. Findings of the Preparation and Integration Phases}

The forms of ICT skills activities include: (i) simple to complex; (ii) readiness of SLD; (iii) connect learning with the real world; (iv) diversification of ICT activities; and (iv) skills that can be applied by SLD either in school or in the workplace. This Fuzzy Delphi questionnaire consists of two main sections: namely the form of activities and the integration of universal learning design principles in the ICT skills development in SLD. The Fuzzy-7 scale was used to obtain the consensus of the Fuzzy Delphi panel in developing ICT designs. Findings were calculated by using Microsoft Excel to obtain the threshold value, (d), percentage agreement and defuzzification value. By doing so, the panel's agreement on an item in this questionnaire can be known.

The forms of activities in the ICT component are as in Table 4.1. The findings of the study showed that all Fuzzy Delphi panels agreed with T1, T2, T3, T4 and T5 in the ICT component. This agreement can be seen from the threshold value (d) for the whole activity and the construct value is 0.12 , which is smaller than the value of 0.2 . These findings prove that a consensus value has been reached. The agreement of the Fuzzy Delphi panel had been reached by $100 \%$ and clearly proves that all activities in ICT components are important for SLD. The described above corresponds the results of Ukrainian experts.

\begin{tabular}{|c|c|c|c|c|c|c|c|c|c|}
\hline \multirow[t]{2}{*}{ Code } & \multirow[t]{2}{*}{ Activity Form } & \multicolumn{2}{|c|}{ Triangular Fuzzy Numbers } & \multicolumn{3}{|c|}{ Defuzzification Value } & \multirow{2}{*}{$\begin{array}{l}\text { Score } \\
\text { Fuzzy } \\
(A)\end{array}$} & \multirow{2}{*}{$\begin{array}{l}\text { Expert } \\
\text { Agreement } \\
\text { Results }\end{array}$} & \multirow{2}{*}{$\begin{array}{l}\text { Item } \\
\text { Priority/ } \\
\text { Position }\end{array}$} \\
\hline & & $\begin{array}{l}\text { Value } \\
\text { Threshold } \\
\text { (d) }\end{array}$ & $\begin{array}{l}\text { Expert } \\
\text { Agreement } \\
\text { Percentage } \\
(\%)\end{array}$ & $\mathrm{m}_{1}$ & $\mathrm{~m}_{2}$ & $\mathrm{~m}_{3}$ & & & \\
\hline $\mathrm{T} 1$ & $\begin{array}{l}\text { Simple } \\
\text { complex }\end{array}$ & 0.020 & 100 & 0.845 & 0.973 & 1.000 & 0.939 & Accept & 1 \\
\hline $\mathrm{T} 2$ & $\begin{array}{l}\text { Student } \\
\text { Readiness }\end{array}$ & 0.029 & 100 & 0.809 & 0.945 & 0.991 & 0.915 & Accept & 2 \\
\hline $\mathrm{T} 3$ & $\begin{array}{l}\text { Connecting with } \\
\text { the real world }\end{array}$ & 0.030 & 100 & 0.664 & 0.855 & 0.973 & 0.830 & Accept & 5 \\
\hline $\mathrm{T} 4$ & $\begin{array}{ll}\text { Various } & \text { ICT } \\
\text { Activities } & \end{array}$ & 0.020 & 100 & 0.76 & 0.891 & 0.973 & 0.867 & Accept & 4 \\
\hline T5 & $\begin{array}{l}\text { Selecting } \text { ICT } \\
\text { skills that can be } \\
\text { applied while } \\
\text { studying } \\
\text { working }\end{array}$ & 0.020 & 100 & 10 & 0.773 & 0.936 & 1.000 & 0.903 & 3 \\
\hline & Total & 0.120 & 100 & & & & & & \\
\hline
\end{tabular}

Table 4.1 Overall Value of Activities in Information and Communication Technology for SLD 
In terms of activity position, the majority of the Fuzzy Delphi panel had reached agreement through a "strongly agree" scale on the activities in the ICT skills component. This agreement was proven when the value for defuzzification was between 0.830 to 0.939 which interprets that the agreement value of the Fuzzy Delphi panel had reached a scale of $83 \%$ to $93 \%$ in this questionnaire. In terms of positioning, activity 1 (simple to complex) was essential in ICT skills. Meanwhile, activity 2 (SLD readiness level) was the second activity required in developing ICT skills of SLD. Next is activity 5 (ICT skills that can be applied by SLD while studying and working), activity 4 (various ICT activities) and the last requirement is activity 3 (connecting learning with the real world). The findings of the study in the form of ICT skills activities, the highest position based on the agreement of experts in ICT is on the statement of learning content ranging from simple to complex with a defuzzification value of 0.939 .

\section{B. Findings on the Assessment Phase}

This study presents activities that can help SLD achieve career education learning information online by using ICT skills for SLD. The findings of the study showed that the expert panel agreed that simple to complex activities, student readiness, basic skills that can be applied by SLD either in education or in the workplace, connecting learning with real world and diversifying ICT skills activities.

Morrison's (2012) study showed that SLD needs to be exposed to complex activities because SLD is a digital generation, which is born in a digital world and digitally minded. So, they need challenging learning to increase their level of motivation. However, different findings were obtained when the expert panel agreed that SLD requires a level of learning that ranges from easy to difficult. This situation may be due to the needs and abilities of SLD that differ in understanding learning material and even this action is also done to reduce the dropout of SLD in achieving the latest and quality information.

This study also shows that the readiness of SLD in accessing information by using ICT can be formed if they are exposed to the right special sources. These findings indicate that SLD need to have specialized resources that are indeed available for information on their vocational education field to ensure that they achieve appropriate quality learning information. This finding is in line with the study of William and Hennig (2015) that the search for learning information would be easier if the SLD could identify the websites they wanted. This action can also ensure that the learning information obtained by them is of quality, authentic and up to date.

Furthermore, this study has also found that SLD need to be exposed to basic ICT skills that can be applied in their education and employment. These findings are in line with a recent study by Smith (2015) who explained that the skills of sending and receiving e-mails, identifying the right source site, the skills of using book marks, undo function and refresh function, sending and attaching documents in e-mail, skills using search engines (Google, InfoSeek) and building networks with teachers and friends are basic skills that need to be mastered by SLD during high school and in their workplace later. 
It is also found in this study that the effective delivery of information to SLD is possible by using video. It enables connection of SLD with real learning situations providing SLD a feeling of being in a real situation while Rosen (2013) opines that using video can facilitate a description, stimulate various senses and increase learning information accessibility for SLD. Based on this basis, e-Jejak uses video as one of the ways to convey career education information to SLD.

The expert panel also agreed that ICT skills developing should not only be focused on accessing educational information but also help SLD build communication networks with public and private educational institutions online. Although these findings are in line with the findings of Noraini et al. (2015) on the importance of educational agency involvement to SLD, however, the approach used was different. The current practice used by Noraini and her peers involves talks and visits.

In the current research SLD were forced to communicate with special education teacher only in the educational institutions. Therefore, it is not surprising if SLD have limited knowledge about the variety of educational institutions available for them (Povenmire et al. 2015). Therefore, ICT provides location map services, telephone numbers, addresses and e-mail to facilitate SLD to build a good relationship with public and private educational institutions.

SLD were exposed to basic skills in ICT so that they could access information in their field of vocational education. Finally, Brunner (1998) emphasized that increasing individual learning motivation should be based on real-life situations. For this purpose, SLD were provided with real learning situations and involved into activities enabling communication networks between them and public/private institutions. All these activities were provided to stimulate and motivate them to work hard to achieve the desired goals.

\section{CONCLUSION AND SUGGESTION}

Developing of ICT skills in SLD was based on the Implementation of the Universal Learning Design and contained of three stages: Preparation Phase, Integration Phase and Assessment Phase. Designing the content of the activities to develop ICT skills and providing the learners with the content to practice their digital skills were the goals of the Preparation and Integration Phases. Determining the quality of SLD's abilities to practice digital skills became the task of the Assessment Phase. In order to summarize the results of the Preparation and Integration Phases qualitative data analysis and Fuzzy Delphi method were used. However, for analyzing the results on the Assessment Phase only total scores were used.

The total number of panel of experts taking part in the Preparation and Integration Phases is 30 , among which there are policy makers ( 5 experts in Malaysia and 25 experts in Ukraine) and policy implementers (6 and 30 people sequentially). While, the number of SLD participating in the Assessment Phase of the research is 55 in Malaysia and 48 in Ukraine. 
The most valuable findings of the study lie in the defining the type and minimal quantity of the activities, needed for effective ICT skills developing with SLD, and in the agreement of the experts in need to provide the learning content ranging from simple to complex (with a defuzzification value of 0.939). Based on the findings of the Preparation and Integration Phases, the panel of experts suggested that there should be at least 5 activities for effective development of ICT skills with SLD. ICT was used to provide videos to connect SLD with real learning situations and specially tailored activities, involving SLD in communication network between them and public and/or private institutions. All these activities were aimed to stimulate and motivate the students to work hard to achieve the desired goals. The results of the Assessment Phase proved that having completed the tasks, SLD became able to use their digital skills for solving real life situations, for online communication with the teachers and institutions.

Career education programs need to ensure that all of the students are able to access the same learning information. If this requirement cannot be met, the gap in students' achievements, especially SLD's ones will be deepen from year to year. Thus, there is a need to design career education programs for SLD started from the lower secondary school level. At the same time, career education programs based on the Universal Learning Design implementation should also be adopted to enable all SLD to access the latest and relevant learning information. Based on that need, as a result of collaboration between SLD, SLD's parents, SLD's teachers and professionals wishing SLD to conduct a prosperous life in the future a special software was developed.

This career education program was designed to meet the needs of SLD and known as "ICT skills". Indirectly, this study has significant value in the field of knowledge, because the software development was based on sound educational theories and practices as well as on the opinions of experienced experts in the field of Special Education, ICT, and Psychology/Counseling. Finally, the findings in this study allow "ICT skills" to be used as a guideline in designing a virtual career education program that can not only meet the needs of SLD but also the needs of special education teachers and encourage them to 21 st century teaching.

\section{REFERENCES}

Aina, R.M.R. (2010). Comparisons of Affirmative Action in Employment for People with Disabilities in Malaysia and The United States. 127.

Bahagian Pendidikan Khas. (2015). Maklumat Pendidikan Khas. Putrajaya: Kementerian Pendidikan Malaysia.

Bowlsbey, J.H. (2013). Computer-Assisted Career Guidance Systems: A Part of NCDA History. The Career Development Quarterly. 61: 181-195.

Bouck, E.C. \& Hunley, M. (2014). Technology and Giftedness. Advances in Special Education 26: 191-210. 
Burgstahler, S. \& Cronheim, D. (2001). Supporting peer-peer and mentor-protege relationships on the Internet. Journal of Research on Technology in Education 34(1): $59-74$.

Brucker, D. L., Mitra, S., Chaitoo, N. \& Mauro, J. (2015). More Likely to Be Poor Whatever the Measure: Working-Age Persons with Disabilities in the United States. Social Science Quartely, 96(1): 273-296.

Catalano A. (2014). Improving Distance Education for Students with Special Needs: A Qualitative Study of Students' Experience with an Online Library Research Course. Journal of Library \& Information Services in Distance Learning, 8(1-2). 2014:1731

Clancy M., Gardner, J. (2017). Using Digital Portfolios to Develop Non-Traditional Domains in Special Education Settings. International Journal of e-Portfolio, 7, no. (1), 93-100.

Creswell, J. W. (2008). Designing and Conducting Mixed Methods Research. Thousand Oaks, CA: Sage Publications, Inc.

Daud, A. (2014). Because Teaching is Like a Plantation of Dakwah: Understanding Complexities in Choosing to be a Teacher in Indonesia. Australian Journal of Educational and Developmental Psychology, 14, 51-59.

Daud, A. (2019). Teaching Writing Using Google Apps for Education (GAFE). Indonesian Journal of Economics, Social, and Humanities, 1(1), 17-24.

Eliwarti, E., \& Maarof, N. (2014). The Effects of Types of Writing Approaches on EFL Students' Writing Performance. Proceedings of ISELT FBS Universitas Negeri Padang, 2, 112-119.

Eliwarti, E., \& Maarof, N. (2017). The Students' Perceptions of the Strategies in the Process Approach. International Journal of Educational Best Practices, 1(1), 67-82.

Ferri, D. \& Giannoumis, G. A. (2014). A revaluation of the cultural dimension of disability policy in the European Union: The impact of digitization and web accessibility. Behavioral Sciences \& the Law 32(1): 33-51.

Handrianto, C., Rasool, S., Rahman, M. A., Musta`in, M., \& Ilhami, A. (2021). Teachers` Self-Efficacy and Classroom Management in Community Learning Centre (CLC) Sarawak. Spektrum: Jurnal Pendidikan Luar Sekolah (PLS), 9(2), 154-163.

Handrianto, C., Salleh, S. M., \& Chedi, J. M. (2020). The Correlation between TeachingLearning Quality and Students` Motivation to Study in Yogyakarta`s Bimbel. Spektrum: Jurnal Pendidikan Luar Sekolah (PLS), 8(4), 527-537.

Handrianto, C., \& Salleh, S. M. (2019). The Environmental Factors that Affect Students from Outside Java Island to Choose Yogyakarta's Bimbel. International Journal of Environmental and Ecology Research, 1(1), 27-32. 
Hargreaves, J. \& Walker, L. (2014). Preparing disabled students for professional practice: Managing risk through a principles-based approach. Journal of Advanced Nursing 70(8): 1748-1757.

Hegarty, J., Bostock, S. \& Collins, D. (2000). Staff Development in Information Technology for Special Needs: A New Distance-Learning Course at Keele University. British Journal of Educational Technology, 31(3):199-212.

IDEA. (2004). Individual with Disabilities Education Improvement Act. (Act 135).

Khalil, M.A. (2008). Promoting Success: Mentoring Students with Disabilities Using New Technologies in Higher Education. Library Hi Tech News. 1: 8-12.

Klein A. (2021). The COVID-19 Economy Is Putting Vulnerable Students' Career Prospects at High Risk. Education Week. March 02, 2021.

Larwin K. H., Erickson M. J. (2016). The Potential Impact of Online/Distance Education for K-12 Special Education Students: A Meta-Analytic Investigation. International Journal of Elementary Education, 5(1), 8-16.

McDonnell, J., Jameson, J.M., Riesen, T., Polychronis, S., Crockett, M.A., \& Brown, B.E. (2011). A comparison of on-campus and distance teacher education programs in severe disabilities. Teacher Education and Special Education, 34, 106-118.

Mohd Ridhuan, M. J., Saedah, S., Zaharah, H., Nurulrabihah, M. N. \& Ahmad, A. S. (2014). Pengenalan Asas Kaedah Fuzzy Delphi dalam Penyelidikan Reka bentuk Pembangunan. Bangi: Minda Intelek.

Morgan, R.L., Morgan, R. B., Despain, D. \& Vasques, E. (2006). I Can Search for Jobs on the Internet. AWebSite That Helps Youth in Transition Identify Preferred Employment. Teaching Exceptional Children, 38(6): 6-11.

Morrison, G. (2012). Early Childhood Education Today. Ed ke-12. Upper Saddle River, NJ: Pearson Education.

Ng'ambi, D. \& Johnston, K. (2006). An ICT-mediated Constructivist Approach for Increasing Academic Support and Teaching Critical Thinking Skills. Educational Technology \& Society, 9(3): 244-253.

Nkansah, G.B. \& Unwin, T. (2010). The Contribution of Icts To The Delivery of Special Educational Needs in Ghana: Practices and Potential. Information Technology for Development, 16(3): 191-211.

Noraini, A., Mohd Hanafi, M.Y., Abang Adam, A.D., dan Nur Aishah, A. (2015). Vocational Education as a Career Pathway for Student with Learning Disabilities: Issues and Obstacles in the Implementation. International Journal of Education and Social Science 98-104. 
Ochs, L. A. \& Roessler, R. T. (2004). Predictors of career exploration intentions: A social cognitive career theory perspective. Rehabilitation Counseling Bulletin. 47: 224-233

Pestana, C. 2015. Exploring The Self-Concept Of Adults With Mild Learning Disabilities. British Journal of Learning Disabilities, 43:16-23.

Povenmire, T.K., Diegelmanna, K., Crumpa, K., Schnorrb, C., Testa, D., Flowersa, C. \& Aspela, N. (2015). Implementing CIRCLES: A new model for interagency collaboration in transition planning. Journal of Vocational Rehabilitation, 42: 51-65

Raghavendra, P. P., Newman, L. L., Grace, E. E., \& Wood, D. D. (2013). ' I could never do that before': effectiveness of a tailored Internet support intervention to increase the social participation of youth with disabilities. Child: Care, Health \& Development, 39(4): 552-561.

Rojewski, J. W. (2002). Career Assessment For Adolescents With Mild Disabilities: Critical Concerns For Transition Planning. Career Development for Exceptional Individuals 25: 73-95.

Rosen, D. J. 2013. Career Exploration: Web-based Videos. Journal of Research and Practice for Adult Literacy, Secondary, and Basic Education, 2(1): 58-60.

Safani, B. Mohd Hanafi, M.Y. \& Mussidiq, M. R. (2013). Computer-assisted teaching and learning among special education teachers. Asian Social Science 9: 87-94. Salamanca Statement. 1994. The Salamanca Statement: On Principles, Policy and Practice in Special Needs Education. tahun 1994.

Shevtsov, A.G., Lastochkina, O.V., Nykonenko N.V. (2020). Special Education Teachers' Training in Ukraine and Abroad in the Conditions of Distance Education Emergence Implementation. Information Technologies and Learning Tools, 77(3).

Smith. C.L. (2015). Technology Literacy Skills Needed in Further Education and/or Work: A Delphi Study of High School Graduates' Perspectives. Tesis Dr. Fal, University of South Florida.

Trainor, A. A., Smith, S. A. \& Kim, S. (2012). Four Supportive Pillars in Career Exploration and Development for Adolescents with LD and EBD. Intervention in School and Clinic, 48(1): 15-21.

Wehman, P.H., Inge, K.J., Brooke, V.A. \& Paul, H. (2007). Realwork for Real Pay: Inclusive Employment For People With Disabilities. Brookes: Baltimore.

Williams, P. \& Hennig, C. (2015). Effect of Web Page Menu Orientation on Retrieving Information by People With Learning Disabilities. Journal Of The Association For Information Science And Technology. 66(4):674-683.

Zalaquett, C. P. \& Osborn, D. S. (2007). Fostering counseling students' career information literacy through a comprehensive career web site. Counselor Education and Supervision, 46: 162-171. 